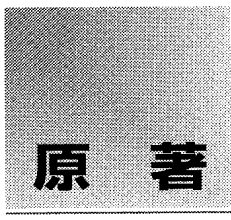

論文受付

1997年12月 4 日

論文受理

1998年9月1日

Code No.251

\section{ヘリカルCTによる体軸力向分解能の改善}

池田 秀 - 宗像浩二・吉田国弘 - 早川 護 - 石井義照 - 高橋正男 - 川又郁夫

\section{1. 緒 言}

ヘリカルCTの普及により，三次元画像や MPR (multiplanar reformation) 画像が臨床上実用化されてき た。以前では, CT画像 = axial画像であり, 顔面の coronal画像を撮影する際は，被検者に困難な体位を要 求する方法のみで，被検者の状態によっては，不可能 であった。これに対しMPR画像は，撮影後に再構成
することにより, coronal, sagittalのみならず任意の 断面像を得ることができる。これは，CTの画像情報 が増すとともに, coronal, sagittal画像が一般的に用 いられるMRI画像やSPECT画像との比較にも有用であ る.

しかし，一般的にMPR画像はaxial画像に比べ体軸 方向の空間分解能が低下することとへリカルスキャン

\title{
Examination of the Improvement of Longitudinal Resolution by Using Helical CT
}

\author{
SHU IKEDA • KOJI MUNAKATA · KUNIHIRO YOSHIDA • MAMORU HAYAKAWA \\ YOSHITERU ISHII - MASAO TAKAHASHI and FUMIO KAWAMATA
}

Department of Radiology, Tokai University Hospital

Received Dec. 4, 1997; Revision accepted Sept. 1, 1998; Code No. 251

\section{Summary}

Multiplanar reformation (MPR) images of helical CT suffer from poor longitudinal resolution and the "stairstep" artifact. We attempted to solve these problems by studying five scanning modes ( 1 mm collimation with 1 pitch; $1 \mathrm{~mm}$ collimation with 2 pitches; $3 \mathrm{~mm}$ collimation with 0.5 pitch; $3 \mathrm{~mm}$ collimation with 1 pitch; and $5 \mathrm{~mm}$ collimation with $1 \mathrm{pitch}$ ). Longitudinal resolution was found to be affected more by slice collimation than table feed. The stair-step artifact consists of a rotation effect and aliasing effect. The rotation effect was a cyclic artifact, and the cycle was dependent on table feed. In order to solve these problems, we employed a restoration filter to improve longitudinal resolution and a band filter to remove the stair-step artifact. In the clinical images, we used three scanning modes $(1 \mathrm{~mm}$ collimation with 1 pitch; 3 mm collimation with 0.5 pitch; $3 \mathrm{~mm}$ collimation with 1 pitch). In conclusion, these problems in scanning images were completely solved by using $1 \mathrm{~mm}$ collimation with 1 pitch. However, we were not able to solve the problems in scanning images using $3 \mathrm{~mm}$ collimation with 0.5 and 1 pitch.

Key words: Computed tomography $(C T)$, Helical scan, Longitudinal resolution, Stair-step artifact, Multiplanar reformation (MPR) 
特有の階段状ア一チファクトの出現か問題となる。こ

の階段状アーチファクトとは，Wangらが発表したstairstep artifact rotation effect $と$ 同一のものである!.

そこで,この二つの問題，つまり体軸方向の空間分 解能の低下と, 階段状アーチファクトの特性を調ベる とともに改善を試みたので報告する。

\section{2. 理 論}

\section{2-1 体軸方向の空間分解能改善}

Fig. 1a，bに体軸方向の空間分解能改善の手順を示 古.この改善は，ここで示すようにaxial画像に対し体 軸方向の空間分解能の低下を補うことが目的である。

空間分解能改善フィル夕は, 式(1)に 示高.

$$
\begin{aligned}
F I(\omega)= & A(\omega) \div L(\omega) \quad \cdots \cdots(1) \\
F I(\omega): & \text { 空間分解能改善フィル } \\
& \text { 夕 } \\
A(\omega): & \text { axial画像のMTF } \\
& \text { (modulation transfer } \\
& \text { function) } \\
L(\omega): & \text { 体軸方向のMTF }
\end{aligned}
$$

空間周波数上で作成した空間分解能 改善フィル夕式(1)を実空間上に変換 し，体軸方向に畳込方方法を用い 万.

\section{2-2 階段状アーチファクトの改善}

Fig.1c，d，eに階段状ア一チファク 卜除去の手順を示す。階段状ア一チ ファクトは，周期性があるため，あ る周波数に強調成分が現れる。ここ を除外し，周囲のデータにより補間 する。この補間データと階段状ア一 チファクトによる周波数強調成分の 割合を除去したものが，階段状ア一 チファクト除去フィル夕となる。こ の除去フィルタを式(2)に示す.

$$
\begin{aligned}
& F 2(\omega)= I(\omega) \div W(\omega) \quad \cdots \cdots(2) \\
& F 2(\omega): \text { 階段状アーチファクト } \\
& \text { 除去フィルタ } \\
& I(\omega): \text { 補間データ } \\
& W(\omega): \text { 基画像の体軸方向の周 } \\
& \text { 波数成分 }
\end{aligned}
$$

この式(2) を基画像の体軸方向の周波 数領域に掛けることにより除去が可 能である。

\section{3. 実 験}

\section{3-1 使用機器}

CT装置：GE社 AdvantageSG 
画像処理装置：Power Macintosh 8100/100

使用言語

: Symantec $\mathrm{C}++$

$0.2 \mathrm{~mm}$ 鉛玉

発泡スチロール製の箱 $(1$ 辺 $15 \mathrm{~mm})$

アクリルラダーファントム $(0.2$ line pair $/ \mathrm{mm})$

卵の殻

\section{3-2 方 法}

\section{3-2-1 空間分解能の測定}

$0.2 \mathrm{~mm}$ 鉛玉をガントリの中心に置きスキャンし， 体軸方向とaxial画像の点拡が function: PSF) 存め, MTFを算出した。なお，体軸 方向では，X線ビーム幅とpitchを变化させた 線ビーム幅 $(\mathrm{mm}) /$ テーブル送り $(\mathrm{mm} / \mathrm{rot}))$ ）条件は, 下記の通りである。

体軸方向 $(\mathrm{X}$ 線ビーム幅 $(\mathrm{mm}) / \mathrm{pitch}) ： 1 / 1,1 / 2,3 / 0.5$,

$$
3 / 1,5 / 1
$$

axial画像の再構成関数は，standardとした。

このMTFを基に，体軸方向の空間分解能改善フィル 夕を決定した。

\section{3-2-2 階段状アーチファクトの周波数の測定}

発泡スチロール製の箱に水を入れ，体軸方向に45度 傾けて設置した状態でスキャンを行った。このデータ を0.2mm間隔で画像再構成し，coronal画像を作成し た。このcoronal画像の水の部分に現机た，体軸方向に 直行する階段状アーチファクトの周波数を求めた。撮 影条件は，120kV，200mA，X線ビーム幅とテーブル 送りは，空間分解能の測定と同様に变化させた。この 階段状アーチファクトの周波数を基に，除去す心゙き周 波数を求めた。

3-2-3 アーチファクトの改善(アクリルラダーファン トムの実験結果より)

水を入れた発泡スチロール製の箱の中に，アクリル ラダーファントムを設置し，ガントリに平行と45度傾 けた 2 種類の状態でスキャンを行った。これを $0.2 \mathrm{~mm}$ 間隔で画像再構成した。条件は，120kV，200mA，X 線ビーム幅 $1 \mathrm{~mm}$, pitch 1 , FOV $102 \mathrm{~mm}$, matrix $512 \times 512$ とした。ここでFOVを $102 \mathrm{~mm}$ とした理由は， ピクセルサイズを $0.2 \mathrm{~mm}$ とすることで， $0.2 \times 0.2 \times 0.2 \mathrm{~mm}^{3}$ の正四面体ボクセルとするためである：このデータか ら，coronal画像を作成した。このcoronal画像に体軸 方向の空間分解能改善フィル夕を掛け，階段状アーチ ファクトを含む周波数を除去した。

\section{3-2-4 アーチファクトの改善(卵の壳を用いた実験結} 果より)

発泡スチロール製の箱の中に卵の款を設置した。卵 の殸の内外は水である。これをスキャンした。条件よ
画像再構成間隔は，アクリルラダーファントムの実験 と同様である。このデータから, coronal画像を作成 し，体軸方向の空間分解能改善フィルタを掛け，階段 状ア一チファクトを含吉周波数を除去した。この卵の 款の設置とMPRのcoronal面をFig.2に示す。

\section{3-2-5 臨床画像の改善}

臨床画像の種類と撮影条件は，下記の通りである。 またママトリクスサイズは，512×512とした(X線ビー 么幅 $(\mathrm{mm}) / \mathrm{pitch} /$ 再構成間隔 $(\mathrm{mm}) / \mathrm{FOV}(\mathrm{mm}))$.

眼窩：(1/1/0.4/205)

顔面：(3/0.5/0.4/205)

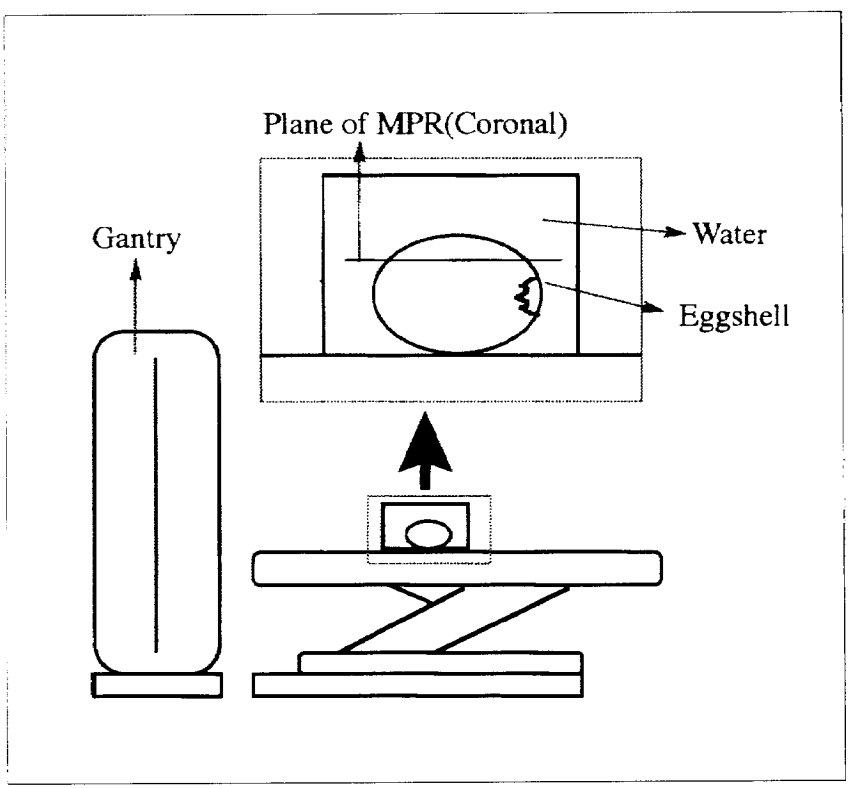

Fig. 2 Schematic diagram of the experimental setup and eggshell.

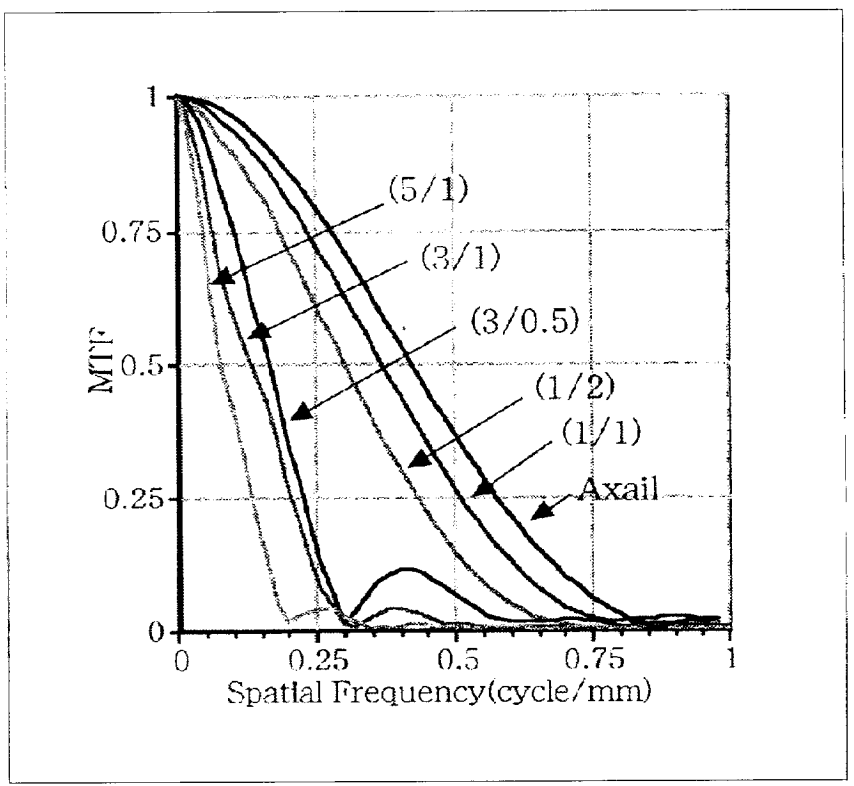

Fig. 3 MTFs of axial slice and longitudinal direction. Helical scanning conditions are the five scanning methods defined in the text (collimation ( $\mathrm{mm}) / \mathrm{pitch}$ ). 
肝藏：(3/1/0.6/307)

上記の撮影部位におけるMPRのcoronal画像を用い， 今回の画像処理を行った.

\section{4. 結 果}

\section{4-1 空間分解能の測定}

検討したaxial画像，および体軸方向のMTFをFig.3 に示す．体軸方向は，X線ビーム幅が狭く，テーブル 送りが遅いほとMTFが良く，テーブル送りよりX線ビ 一ム幅がよりMTFに影響していた。axial画像と体軸

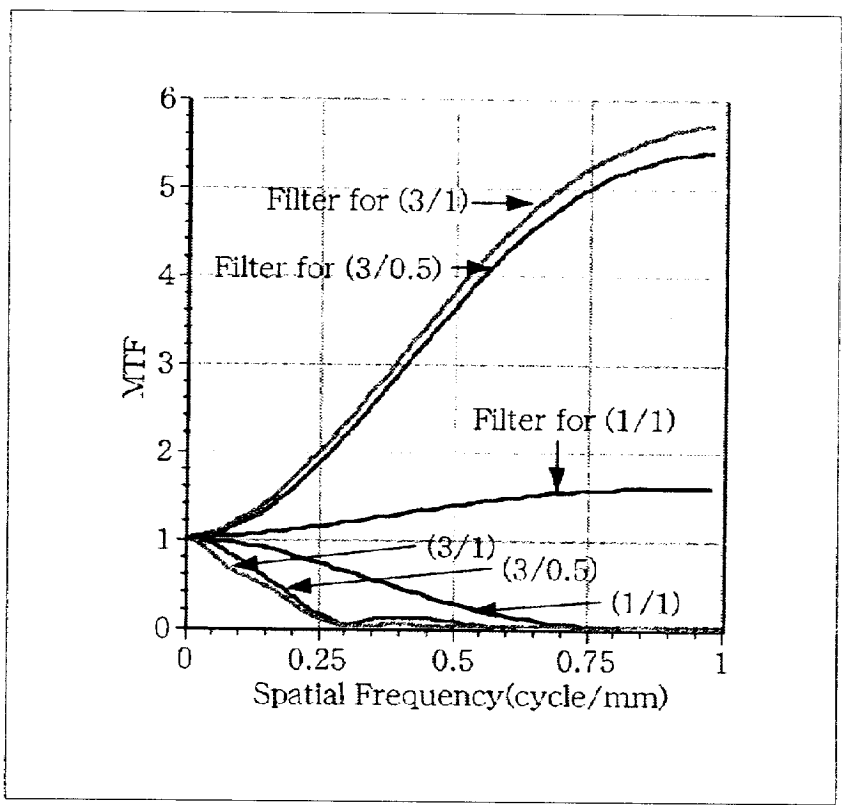

Fig. 4 MTFs of three scanning conditions and restoration filters (collimation ( $\mathrm{mm}$ )/pitch).
方向のMTFを比較すると, 体軸方向で最もMTFが良 いX線ビーム幅 $1 \mathrm{~mm}$ テーブル送り $1 \mathrm{~mm}$ でも，axial画 像のMTFより劣っていた。 axial画像，抢よび体軸方 向のMTFから作成した体軸方向の空間分解能改善つィ ルタをFig.4に示す。ここで示すフィルタは，今回の 実験の臨床画像の改善に用いた種類のみである。

\section{4-2 階段状アーチファクトの周波数の測定}

階段状アーチファクトの周波数をFig.5a， b に示 す。これより，すべてのスキャン条件において，特有 の周期を持つ周波数であることが分かった。そして， これは周波数上で，複数スパイク状に現れていた。こ の周期の最低周波数は，テーブル送りが遅いほど高周 波数に移行していた。

\section{4-3アクリルラダーファントムを用いた改善}

ガントリに対し平行に設置したMPRのcoronal画像 をFig.6aに，45度に設置した画像をFig.7aに示す。こ の画像は, 2 種類ともにaxial画像方向より，体軸方向 の空間分解能が低下していたが，階段状アーチファク トは，45度に設置した画像で強く現れ，平行の画像で は，減少していた。このため，2 種類とも体軸方向改 善フィル夕は掛けているが，階段状アーチファクト除 去フィルタは，45度の画像にのみ行った。これによ り，2 種類とも空間分解能が向上した画像が得ら玌 た。

45度の画像の体軸方向に周波数解析を行った結果を Fig.8に示す。これから，アクリルラダーファントム

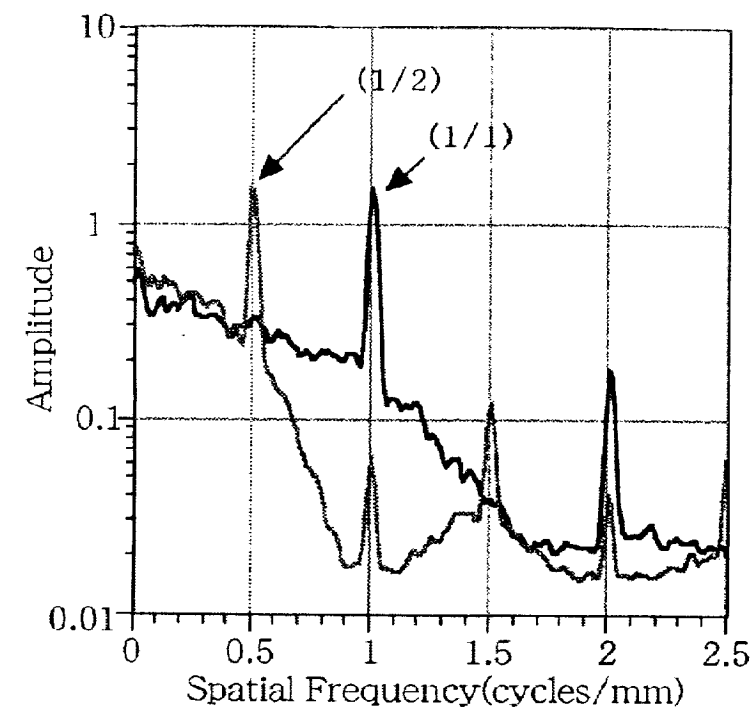

(a)

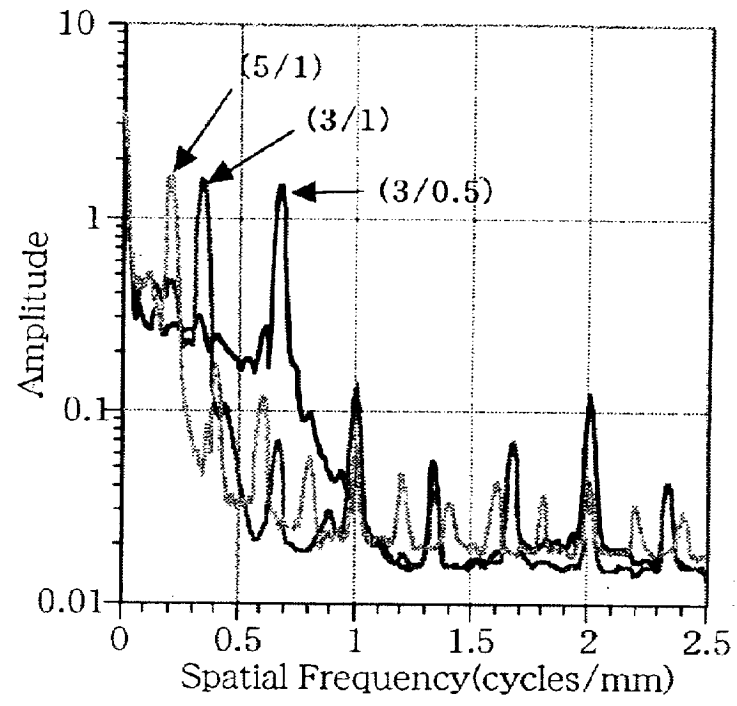

(b)

Fig. 5 Frequency spectra of stair-step artifact obtained under five helical scanning conditions (collimation ( $\mathrm{mm}$ )/pitch). 
自身が持つ周波数と階段状アーチファクトの周波数成 分が混在していることが分かった。

\section{4-4＼cjkstart卵の殻を用いた改善}

MPRのcoronal画像をFig.9に示古。処理前の画像で は，階段状アーチファクトが強く現れていたが，処理 後の画像では消えており卵のような薄い殼でも，この 方法により，再現できることが分かった。

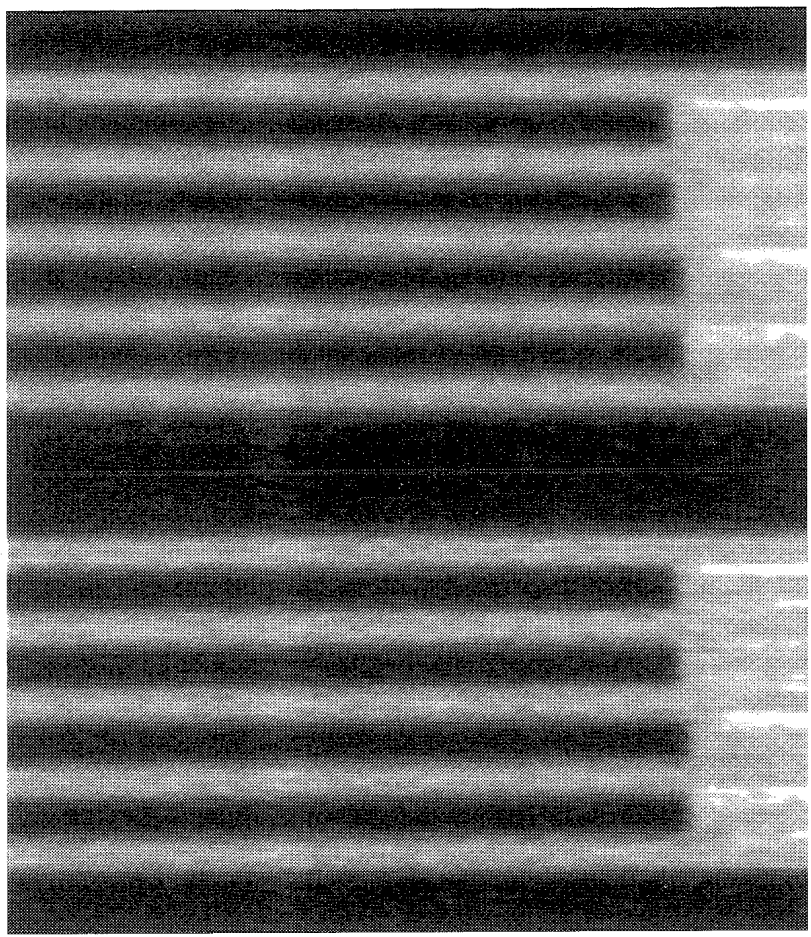

Fig. 6 (a), (b) MPR images of ladder phantom with helical scanning condition of $1 \mathrm{~mm}$ collimation and 1 pitch. Ladder phantom images taken parallel to the gantry. (a) Original ima age, (b) Image after correction.

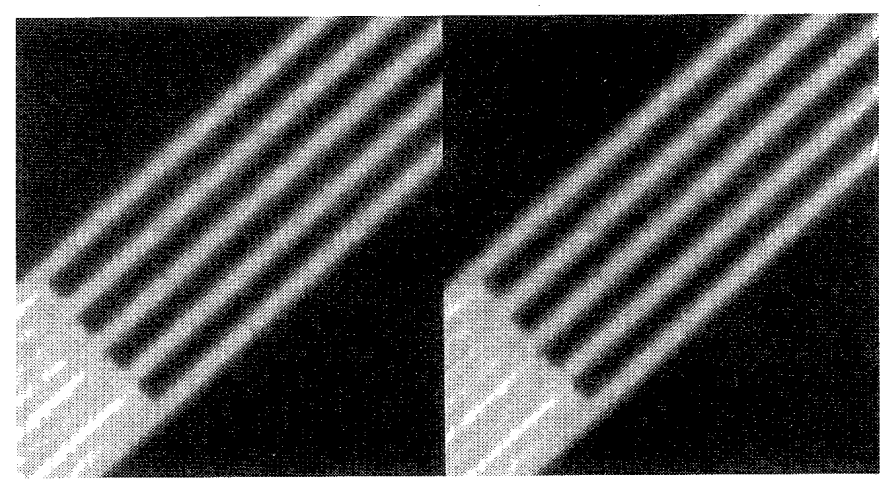

Fig. 7 (a), (b) MPR images of ladder phantom with helical scanning condition of $1 \mathrm{~mm}$ collimation and 1 pitch.

Ladder phantom images taken at an angle of 45 degrees to the gantry. (a) Original image, (b) Image after correction.

\section{4-5 臨床画像の改善}

臨床画像の改善結果をFig.10～12に示す.この画像 処理により，3 種類の画像とも，画質が改善されてい た。また，階段状アーチファクトは軽減されていたが, 体軸方向の空間分解能改善は強調されていなかった。

\section{5. 若 察}

\section{5-1 空間分解能の測定}

テーブル送りよりX線ビーム幅がMTFに影響するの は，パーシャルボリューム効果の影響がテーブル送り よりX線ビーム幅の方が大きいためである。

X線ビーム幅 $1 \mathrm{~mm}$ では, axial画像のMTFとの差は 少ないため，理論で示した式(1)を用いるが，X線ビ 一ム幅 $3 \mathrm{~mm}$ ではaxial画像のMTFとの差は大きく, 式 （1）を用いた改善では，強調が大きすぎ画像に誤差が 生じるため，Fig.4に示すように，強調を弱め画像に 誤差がでない改善フィルタとした。この弱めた度合い は，0.15cycle/mmで30\%である。

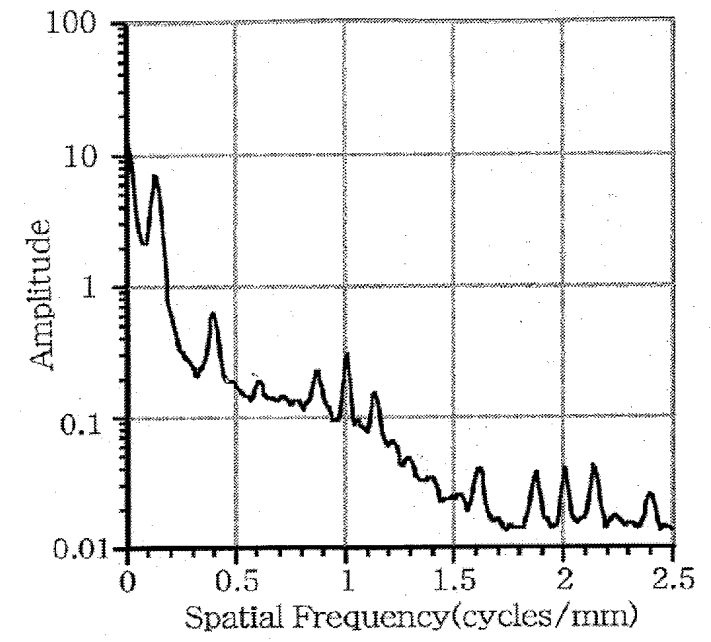

Fig. 8 Frequency spectrum of longitudinal direction obtained from helical scanning data of ladder phantom. Ladder phantom was scanned at an angle of 45 degrees to the gantry.

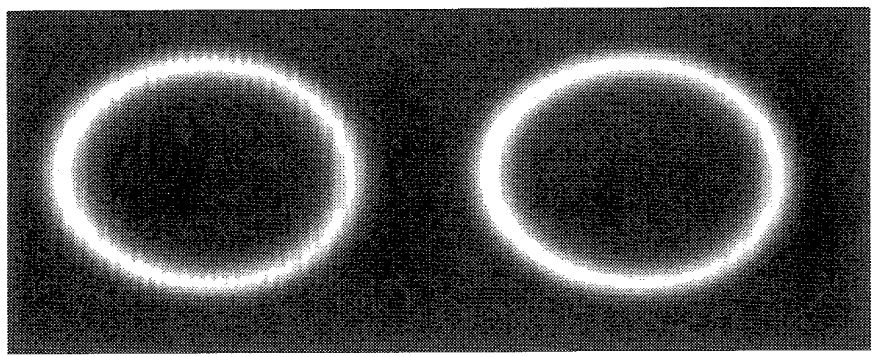

Fig. 9 (a), (b) MPR images of eggshell. (a) Original image, (b) Image after cor- a rection. 

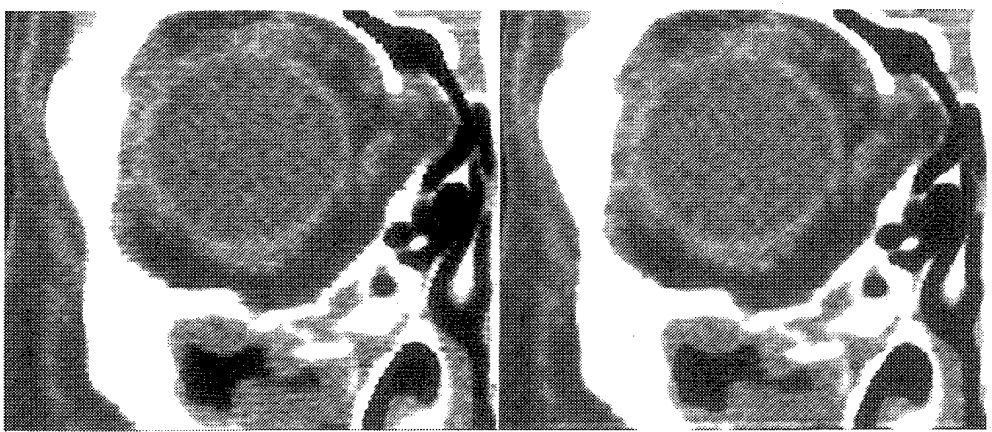

Fig. 10 (a), (b) MPR images of orbit. (a) Original image, (b) Image after correction.
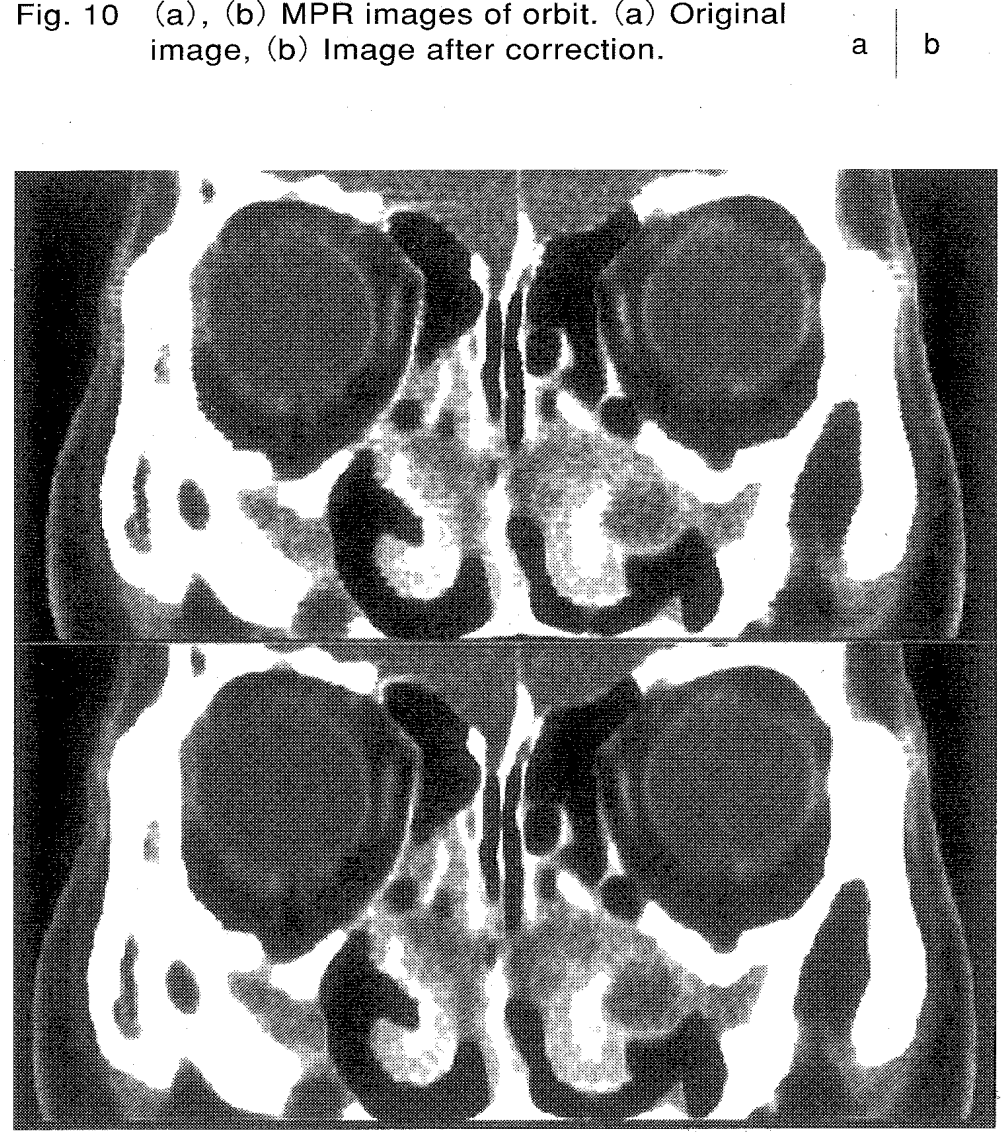

Fig. 11 (a), (b) MPR images of face. (a) Original image, (b) Image after correction.

a

b

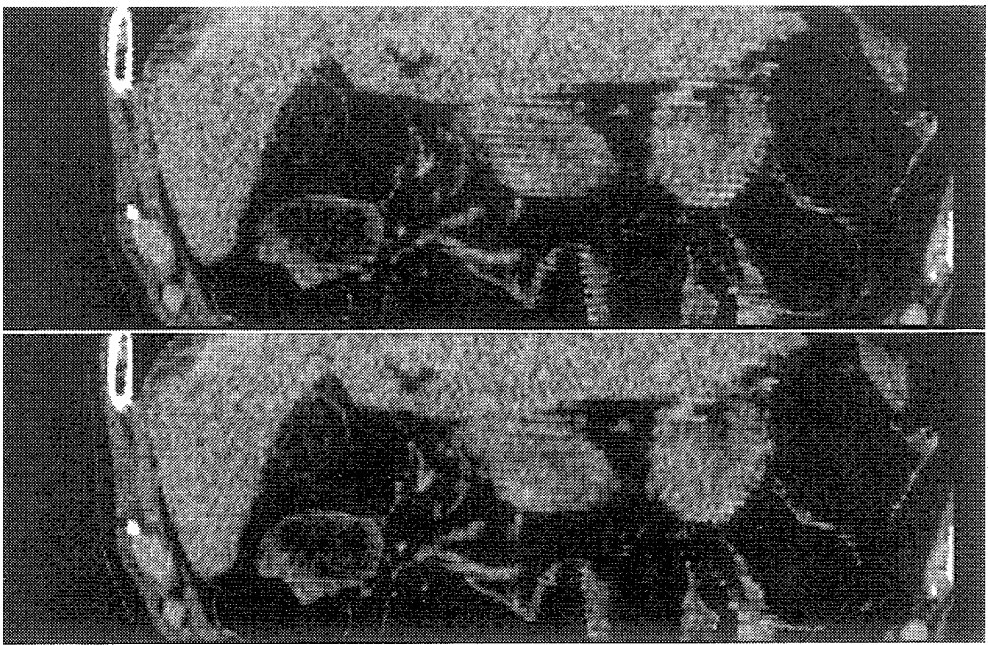

Fig. 12 (a), (b) MPR images of abdomen. (a) Original image, (b) Image after correction.
5-2 階段状アーチファクトの周波数の測定 まず，種々のスキャン条件における周波数 データで, 強調された最低周波数に注目す る、X線ビーム幅 $1 \mathrm{~mm}$ でテーブル送り $1 \mathrm{~mm} /$ rot. (pitch 1)では1cycle/mmに現れ，X線ビー ム幅 $3 \mathrm{~mm}$ でテーブル送り $1.5 \mathrm{~mm} /$ rot. (pitch 0.5) では1.5cycles/mmに現れているようにX線管 1 回転の周期に一致する。これは，Wangら尚の 論文の対象物が斜めに存在する場合に, 対向 データの違いにより生じるローテーション効 果とも一致する.

また,この周波数成分の特徴は, 強調周波 数が一つではなく，基本周波数の整数倍に現 れることである。しかし，階段状アーチファ クトの周波数成分の多くは基本周波数で，そ れに比べ他の周波数成分の割合は，少ないこ とが分かる。

5-3 アクリルラダーファントムを用いた改善 ガントリに対し平行に設置したものでは, 階段状アーチファクトが現れていない. 理由 は，下記の通りである。

階段状アーチファクトは，信号の強度差が あるところに現れる，仮に空気だけ，また は，水だけをスキャンしても現れない。そし て，このアーチファクトは，ガントリに対し 平行に現れる。したがって，ガントリに対し 平行に設置したアクリルラダーファントム は，信号差も平行であるため，階段状アーチ ファクトは画像に現れないのである。逆に， 上記から45度傾けて設置したものでは，階段 状アーチファクトが現れることが理解でき る.

45 度傾けて設置した画像の体軸方向の周波 数解析した結果を考える. 使用したラダーフ アントムは，アクリル厚 $2.5 \mathrm{~mm}$ である。これ を45度傾けて設置したため，体軸方向の厚み は× $\sqrt{2}$ で $3.54 \mathrm{~mm}$ となる。このため, ラダー ファントム固有の周波数は, $0.141 \mathrm{cycle} / \mathrm{mm}$ を基本周波数とし $3 ， 5 ， 7 \cdots$ 倍に現れる.

スキャン条件は，X線ビ一ム幅 $1 \mathrm{~mm}$ でテー ブル送り $1 \mathrm{~mm} /$ rot. (pitch 1) である.よって, 階段状アーチファクトの周波数は，1 cycle/ $\mathrm{mm}$ の整数倍に現れる。

ラダーファントム固有の周波数と階段状アー チファクトの周波数を次式(3)に掛ける. 


$$
W(\omega)=S(\omega) * O(\omega)
$$

$$
\text { * : 曽み込み積分 }
$$

$W(\omega):$ MPR画像の周波数強度

$S(\omega)$ : 階段状アーチファクトの周波数 強度

$O(\omega)$ : アクリルラダーファントム固有 の周波数強度

この結果をFig.13に示す。これより，強調さ 机た周波数は，Fig.8の結果と一致した。

したがって，最終的に画像に現れる結果 は，対象物と階段状ア一千ファクトが周波数 上で雷み込み積分の関係にあることが分か る.

\section{5-4 卵の殻を用いた改善}

実駘に卵の殻を用いたのは，生体の薄い骨 に相当すると考えたからである。この実験か らもラダーファントムの考察で述へたよう に，信号の強度差があるところに㫮段状ア一 チファクトが現机，ガントリと平行に近い卵 の前後端には現机ていない。この階段状ア一 チファクトは，今回の方法で改善さ机てい 万.

\section{5-5 臨床画像の改善}

階段状アーチファクト除去フィルタにより，階段状 アーチファクトの周波数領域を低下させている。この 周波数領域には，対象物がもつ真の信号が含ま机てい るため，その領域の真の信号強度も低下させている。 このことが，体軸方向の空間分解能改善フィルタを掛 けているにもかかわらず，改善が強く現れない理由で ある。

今回の階段状アーチファクト除去力法で，できるた け真の信号を低下させないためには，階段状ア一チフ アクトの周期を信号強度の少ない周波数にすることが 必要である。臨床画像では，通常低周波数はど信号が 多いため，階段状アーチファクトの周期をなるべく高 周波数にすることが望まれる。つまり，スキャン方法 は，テーブル速度を皘くすることである。
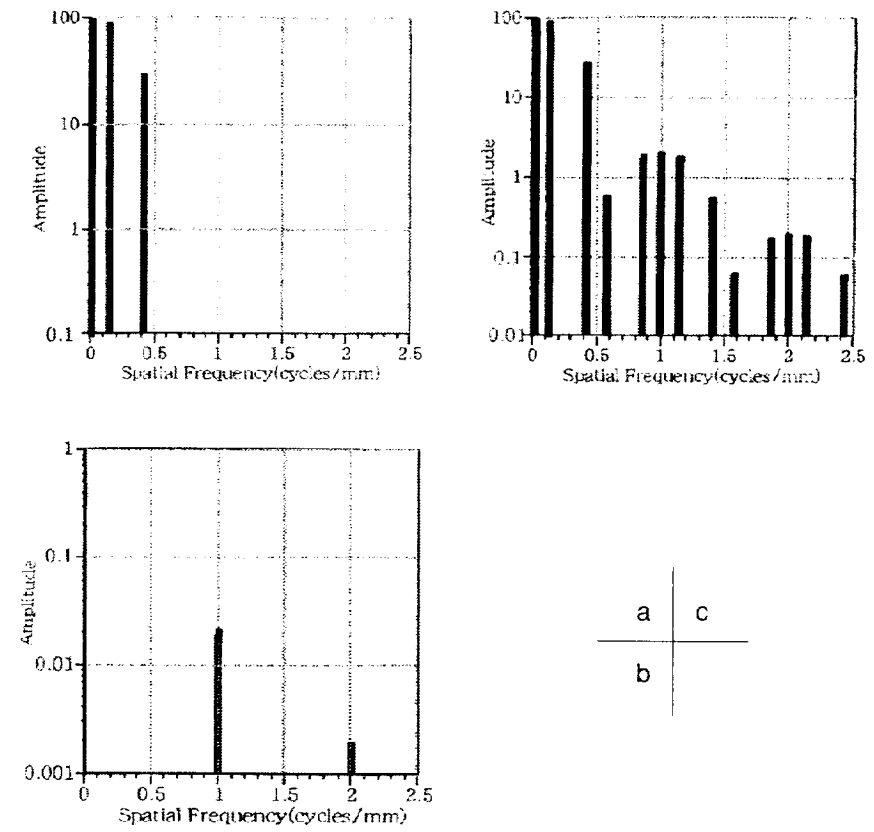

Fig. 13 Simulation of correction employing convolution integral (a) Frequency spectrum of ladder phantom (0.2 line pair/ $\mathrm{mm}$ ). Ladder phantom extends at an angle of $45 \mathrm{de}-$ grees to the gantry.

(b) Frequency spectrum of stair-step artifact corresponding to the helical scanning condition of $1 \mathrm{~mm}$ collimation and 1 pitch.

(c) Result of convolution integral of ladder phantom and stair-step artifact.

\section{6. 結 論}

1) 体軸力向の空間分解能は，X線ビーム幅とテーブ ル送りに依存し，特にX線ビーム幅の影響が大き い.

2)階段状アーチファクトの周期は，テーブル送り ( $\mathrm{mm} /$ rot.) と同一の周期を基本周波数とし, 整数 倍の周波数をもつ。しかし，この周波数成分の多 くは，基本周波数である。

3）本報告の改善方法により，空間分解能の改善が可 能であった。ここで, 階段状アーチファクトの周 波数と対象物固有の周波数は, 畳み込み積分関係 にあるため，階段状アーチファクトの周波数は， 可能な限り高周波数にすることが望まれる。

本報告の改善方法では，体軸方向の空間分解能改善 と階段状アーチファクトの除去に対し，2種類のフィ ルタを用いたが，1 種類の理想的なフィルタを作成す ることは可能と考える。 


\section{参考文献}

1) Wang G, Vannier MW: Stair-step artifact in three-dimensional helical CT: An experimental study. Radiology, 191(1), 7983,(1994).

2) $\mathrm{Hu} \mathrm{H}$ and Fox S: The effect of helical pitch and beam collimation on the lesion contrast and slice profile in helical imaging. Med.Phys., 23(12), 1943-1954, (1996).
3) 花井耕造, 井原文子, 勝田昭一, 他：ヘリカルCTにおける コントラスト分解能と最適画像再構成間隔に関する研究. 日放技学誌，50(12)，1950-1959，(1994).

4）山口道弘，谷口義則，樋口勝己：スパイラルCTを用いた三 次元管腔表示の形状再現性に影響する諸因子について，日 放技学誌，51(7)，819-832，(1995)。

5) 池田 秀：ヘリカルCTによる画像歪みの娭討. TMIT，9 (1), 7-12, (1996).

Fig. 1 体軸方向の分解能改善の手順示示.

(a)，(b) 空間分解能は，MTFで表している.

(a)ヘリカルスキャンでは, 通常axial面に対し体軸方向の分解能は低下している.

(b)したがって, filter $(F I)$ を体軹方向に掛けることにより，体軸方向の分解能をaxial面と同等にする.

(c)，(d)，(e)臨床画像を体軸方向に周波数解析した例を示す。

(c) stair step artifact成分が現れる.

（d）stair step artifact成分を除外した補間データをつくる.

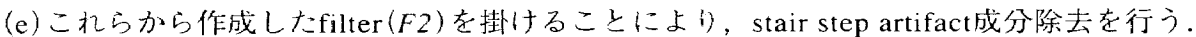

Fig. 2 実騃の設置々卵の款の概要図を示す。

Fig. 3 axial面と体軸方向のMTFを示す。体軸方向のMTFは， 5 種類のスキャン条件で求めた (collimation (mm)/pitch).

Fig. 43 種類のスキャン条件のMTFとそれに対する空間分解能改善filterを示す (collimation (mm)/pitch)。

Fig. 5 stair step artifactの周波数成分を示寸. 5 種類のスキャン条件で求めた (collimation (mm)/pitch).

Fig. 6 アクリルラダーファントムのMPR画像. ガントリに平行にスキャン.

(a) 処理前, (b) 処理㣪.

Fig.7 アクリルラダーファントムのMPR画像. ガントリに対し45度傾けてスキャン.
(a) 処理前, (b) 処理後.

Fig. 8 アクリルラダーファントムのスキャンデータを体軸方向に周波数解析した結果を示寸。アタリルラダーファントムはガン トリに対し45度傾けスキャンした。

Fig. 9 卵の款のMPR画像. (a) 処理前, (b) 処理後.

Fig. 10 眼窝のMPR画像. (a) 処理前, (b) 処理後.

Fig. 11 顔面のMPR画像. (a) 処理前, (b) 処理後.

Fig. 12 肝臓OMPR画像. (a) 処理前, (b) 処理後.

Fig. 13 曽み込み積分によるシミュレーションを示す.

(a)アクリルラダーファントムの周波数を示す。アクリルラダーファントム $(0.2 \mathrm{LP} / \mathrm{mm})$. 45度傾けた状態。

(b) stair step artifactの周波数成分を示市，スキャン条件は，X線ビーム幅 $1 \mathrm{~mm}$ ，テーブル送り $1 \mathrm{~mm} の$ 状態。

(c)アクリルラダーファントムとstair step artifactの周波数成分を盢み込み積分した結果を示す。 